\title{
POLYPODIUM INTERJECTUM AND P. $\times$ MANTONIAE (POLYPODIACEAE) IN THE POLISH SUDETES
}

\author{
Ewa Szczęśniak ${ }^{1}$, Iwona JędrzejczyK, Edyta M. Gola, Remigiusz Pielech, \\ Kamila RecZyŃSKa \& KRZYSZTOF ŚwierKosZ
}

\begin{abstract}
Detailed analyses of micro- and macromorphological features of 247 specimens representing the Polypodium vulgare complex, combined with DNA content measurements, revealed the presence of tetraploid $P$. vulgare s.str., hexaploid $P$. interjectum and the pentaploid hybrid $P . \times$ mantoniae in the Polish Sudetes. For species identification, sporangium structure (number of indurated and basal annulus cells) was found to be the most stable and thus the most valuable and taxonomically significant character. The size of spores and stomata was related to taxon ploidy level, and helped to differentiate the examined taxa. Polypodium interjectum was identified from only one locality in the Pogórze Kaczawskie foothills; $P$. $\times$ mantoniae was more widely distributed, suggesting that it is rather common in the Polish Sudetes. Both newly reported taxa occur mainly on basic or neutral rock in sheltered, shaded or semi-shaded habitats.
\end{abstract}

Key words: distribution, ferns, flow cytometry, Poland, Polypodium vulgare complex

Ewa Szczęśniak \& Remigiusz Pielech, Department of Botany, Institute of Environmental Biology, University of Wroctaw, Kanonia 6/8,50-328Wrocław, Poland; e-mail: ewa.szczesniak@uwredu.pl \& remekpielech@gmail.com

Iwona Jędrzejczyk, Department of Plant Genetics, Physiology and Biotechnology, UTP University of Sciences and Technology, Al. Prof. S. Kaliskiego 7, 85-796 Bydgoszcz, Poland; e-mail: jedrzej@utp.edu.pl

Edyta Gola, Department of Plant Developmental Biology, Institute of Experimental Biology, University of Wrocław, Kanonia 6/8, 50-328 Wrockaw, Poland; e-mail: edyta.gola@uwredu.pl

Kamila Reczyńska \& Krzysztof Świerkosz, Herbarium of the University of Wroclaw, Sienkiewicza 21, 50-335 Wrocław, Poland; e-mail: kamila.reczynska@gmail.com \& krzysztof.swierkosz@life.pl

\section{INTRODUCTION}

The polyphyletic genus Polypodium L. is distributed worldwide (e.g., Haufler et al. 1993; Lu \& Haufler 2013). Species of the genus occur mostly in tropical areas of America, and less frequently in the Old World. The taxonomy of this genus remains unresolved; the number of species is variously estimated at $c a 100$ (Dostál \& Reichstein 1984; Haufler et al. 1993), 150-170 (Hassler \& Swale 2001), and up to 200 (Hennipman et al. 1990). Species recorded in Europe represent the polymorphic Polypodium vulgare complex sensu Shivas (1962). Species identification used to be based mostly on macroscopic features (e.g., Milde 1858; Rothmaler 1929). More recently the karyological delimitation of the taxa proposed by

\footnotetext{
1 Corresponding author
}

Manton (1947, 1950) and Shivas (1961a, b, 1962) is generally accepted.

In Poland almost all collected specimens of Polypodium have been classified as P. vulgare L., as this fern was not previously recognized as a species complex (Zając \& Zając 2001). Polypodium vulgare s.str. is widely distributed and is the most commonly recorded species of this complex. In neighboring countries, two other taxa are present: $P$. interjectum Shivas and $P . \times$ mantoniae Rothm. (e.g., Rothmaler 1994; Benkert et al. 1998; Holub \& Kubát 1999; Kubát 2002; Bureš et al. 2003).

Polypodium interjectum is a hexaploid species which originated due to allopolyploidization of the triploid hybrid $P$. vulgare L. $\times$ P. cambricum L. (P. $\times$ font-queri Rothm.). It is a European taxon with a sub-Atlantic-sub-Mediterranean range, distributed in Western and Central Europe, north- 
wards to Scotland and Norway, and eastwards to the Baltic region (Valentine et al. 1993; Nielsen \& Johnsen 2000; Harmaja 2012). The easternmost European localities are reported from Kaliningrad and southeast of Moscow in Russia, near Rakhov in western Ukraine (Fedorov 1974), and on the Crimean Pennisula (Seregin 2008; Vaszeka \& Bezsmertna 2012). In Poland it was reported from only one locality near Szczecin (Dostál \& Reichstein 1984); its occurrence was not confirmed later. Polypodium interjectum was not included in either edition of the checklist of the Polish flora (Mirek et al. 1995, 2002), nor in the Distribution Atlas of Vascular Plants in Poland (Zając \& Zając 2001), but the station near Szczecin was mentioned by Rutkowski (2006).

Polypodium $\times$ mantoniae is a pentaploid hybrid of $P$. vulgare and $P$. interjectum recorded throughout the shared range of the parental species. The macromorphological features of the parental taxa and the hybrid vary greatly, so a given taxon can be properly delimited only by observation of the micromorphological features of sporangia, spores and stomata (e.g., Shivas 1961a, b; Valentine et al. 1993; Hršak 2000; Bureš et al. 2003; Helánová et al. 2004; Page 2004; Ivanova 2006; Szczęśniak et al. 2012). In Poland the hybrid was first found in 2011 in a pine forest on northern cliffs of Wolin Island (Zenkteler \& Jędrzejczyk 2012).

Morphological similarities hinder species determination within the $P$. vulgare complex. The presence of all three of these taxa in the vicinity of the Polish Sudetes prompted us to undertake detailed research on them, in order to determine which taxa of the $P$. vulgare complex are present in the Polish Sudetes, and their habitat preferences and distribution range. We also sought to find out which micro- and macromorphological characters are most useful for their identification.

\section{MATERIALS AND METHODS}

In 2011 and 2012 we examined 247 specimens from 35 known localities of the $P$. vulgare complex in the Polish Sudetes and their foreland: 25 randomly selected sites, and 10 populations of Polypodium in the Sudetes foreland and foothills that had developed on basic to slightly acid substrate preferred by $P$. interjectum and $P . \times$ mantoniae (Table 1). All sampled sites are sheltered and protected from winter winds, have a rather humid microclimate, and are entirely or partially shaded by deciduous forest.

To identify particular taxa within the $P$. vulgare complex, we analyzed micromorphological features of sporangia (number of indurated annulus cells and annulus basal cells) and measured the size of spores and stomata. All analyses used material from pinnae from the middle parts of sori-bearing leaves. The number of annulus cells was counted in 30 sporangia or in all matured sporangia developed in 5 sori. To measure stomata size, the basal parts of collected and dried pinnae were soaked with warm water for at least $15 \mathrm{~min}$, and strips of the abaxial epidermis were peeled. Next, images of randomly selected stomata were taken with an Olympus BX50 microscope/DP71 digital camera system working with Cell^ ${ }^{\wedge}$ software (Olympus SA, Poland). Spores were also documented with digital images. Then the length of stomata and the length of spores, which in Polypodium are ellipsoidal, were measured along the long axis of the ellipse. These were assessed using AxioVision LE 4.2. (Carl Zeiss MicroImaging GmbH, Germany). Thirty measurements of each specimen were made, except in hybrids; due to the high frequency of aborted spores, each of those specimens had 5-30 measurements made. In addition, macromorphological features were analyzed, including leaf shape, leaf size, and leaf blade/stalk length ratio.

To confirm the species identifications, ploidy level and nuclear DNA content were determined using flow cytometry. For ploidy level estimation, leaves of the tetraploid species $P$. vulgare $(2 \mathrm{n}=4 \mathrm{x}=148)$ were used as a reference standard of known ploidy; those plants were obtained from the Botanical Garden of the University of Wrocław. Genome size was determined in 50 fresh young leaves of ferns from the examined populations, including those typified as $P$. interjectum and $P . \times$ mantoniae on the basis of morphological features and/or habitat, and also doubtful specimens without developed sporangia (Table 1). Leaves of Pisum sativum cv. Set (9.11 pg/2C; Śliwinska et al. 2005) were the internal standard.

Samples were prepared according to Galbraith et al. (1983), with some modifications. Plant tissues of the target species and the standard were chopped with a sharp razor blade in a plastic Petri dish containing $1 \mathrm{~mL}$ nucleus isolation buffer $(0.1 \mathrm{M}$ Tris, $2.5 \mathrm{mM}$ $\mathrm{MgCl}_{2} \times 6 \mathrm{H}_{2} \mathrm{O}, 85 \mathrm{mM} \mathrm{NaCl}, 0.1 \%$ (v/v) Triton X-100; $\mathrm{pH}$ 7.0) supplemented with 4,6'-diamidino-2-phenyl- 
Table 1. List of analyzed populations and taxa of the Polypodium vulgare complex recognized in the Polish Sudetes. * - taxon determination confirmed by flow cytometry, shaded block - localities chosen for their substrate characteristics.

Locality and habitat [ATPOL grid square] \begin{tabular}{l|l|l|} 
P. vulgare & P. interjectum & P. $\times$ mantoniae
\end{tabular}

SUDETES Foreland

1. Wzgórza Strzegomskie hills. Góra Św. Jerzego Mt., W exp., 340 m a.s.1 abandoned basalt quarry, Aceri-Tilietum [BE64]

2. Wzgórza Strzegomskie hills. Góra Krzyżowa Mt., NW exp., 345 m a.s.l., basalt, Galio-Carpinetum [BE64]

3. Wzgórza Kiełczyńskie hills. Gogołów, $\mathrm{N}$ exp., $295 \mathrm{~m}$ a.s.l., abandoned ser pentine rock quarry, degraded oak forest [BE76]

4. Ślęża Massif. Sady, Ślęża Mt., W exp., $350 \mathrm{~m}$ a.s.1., granite, degraded GalioCarpinetum [BE76]

5. Ślęża Massif. Góry Skalne, Ślęża Mt., W exp., 510 m a.s.l., gabbro, HypnoPolypodietum [BE76]

6. Ślęża Massif. Góra Radunia Nature Reserve, NW exp., 560 m a.s.l., serpentine rock, Androsacion vandellii, shaded by oak forest [BE76]

7. Ślęża Massif. Góra Radunia Nature Reserve, NW exp., 500 m a.s.1., serpentine rock, degraded Quercus petraea - Fagus silvatica forest [BE76]

8. Ślęża Massif. Świątniki, NW exp., $180 \mathrm{~m}$ a.s.l., abandoned serpentine quarry, Hypno-Polypodietum [BE77]

9. Wzgórza Niemczańsko-Strzelińskie hills. Gilów, NE exp., 240 m a.s.l., gneiss (?), Hypno-Polypodietum, degraded Galio-Carpinetum [BE97]

10. Wzgórza Niemczańsko-Strzelińskie hills. Szklary, NW exp., 330 m a.s.l., abandoned serpentine quarry, Hypno-Polypodietum [BE97]

11. Wzgórza Niemczańsko-Strzelińskie hills. Zakrzów, W exp., 260 m a.s.l., slate (?) outcrop, Galio-Carpinetum [BE99]

\section{Sudetes FoOTHILL}

12. Pogórze Izerskie foothills. Panieńskie Skały near Lwówek Śląski, N exp $230 \mathrm{~m}$ a.s.1., sandstone, oak-pine forest, Hypno-Polypodietum [AE49]

13. Pogórze Izerskie foothills. Barcinek, Kamienica river valley, W exp., $330 \mathrm{~m}$ a.s.1., granite, Androsacion vandellii [AE69]

14. Pogórze Kaczawskie foothills. Ostrzyca Proboszczowicka Nature Reserve, W, N \& E exp., 480-495 m a.s.1., basalt, Androsacion vandellii, Aceri-Tilietum [BE40]

15. Pogórze Kaczawskie foothills. Bogaczowice, W exp., $290 \mathrm{~m}$ a.s.l., abandoned slate (?) quarry, degraded Galio-Carpinetum [BE42]

16. Pogórze Kaczawskie foothills. Świerzawa, NW exp., 270 m a.s.1., trachybasalt (?) rock near stream, Quercion robori-petraeae [BE52]

17. Pogórze Kaczawskie foothills. Czartowska Skała, N exp., 460 m a.s.1., basalt, Hypno-Polypodietum [BE52]

18. Pogórze Kaczawskie foothills. Wąwóz Myśliborski Nature Reserve, E \& NW exp., 340 m a.s.1., greenstone, Androsacion vandellii, Aceri-Tilietum [BE52]

19. Pogórze Kaczawskie foothills. Wąwóz Lipa Nature Reserve, E exp., 360 m a.s.1., greenstone, Aceri-Tilietum [BE52]

20. Pogórze Kaczawskie foothills. Nad Groblą Nature Reserve, E, W exp., $290 \mathrm{~m}$ a.s.1., greenstone, Aceri-Tilietum [BE52]

\begin{tabular}{|c|c|c}
\hline$+^{*}$ & - & $+^{*}$ \\
\hline$+^{*}$ & - & - \\
\hline$+^{*}$ & - & - \\
\hline+ & - & - \\
\hline+ & - & + \\
\hline$+{ }^{*}$ & - & + \\
\hline+ & - & - \\
\hline+ & - & - \\
\hline+ & - & - \\
\hline+ & - & - \\
\hline+ & & \\
\hline
\end{tabular}

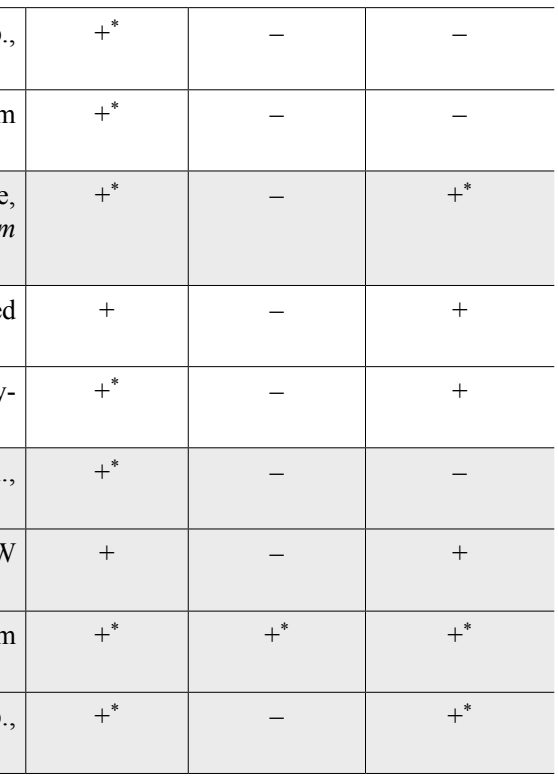


Table 1. Continued.

\begin{tabular}{|c|c|c|c|}
\hline Locality and habitat [ATPOL grid square] & P. vulgare & P. interjectum & P. $\times$ mantoniae \\
\hline $\begin{array}{l}\text { 21. Pogórze Kaczawskie foothills. Schody Mt. near Kwietniki village, W, NW } \\
\text { \& N exp., 340-350 m a.s.1., porphyry, Aceri-Tilietum [BE62] }\end{array}$ & $+^{*}$ & - & $+^{*}$ \\
\hline $\begin{array}{l}\text { 22. Pogórze Wałbrzysko-Bolkowskie foothills. Szczawnik river valley, E exp., } \\
360 \text { m a.s.l., conglomerat, Aceri-Tilietum [BE73] }\end{array}$ & + & - & - \\
\hline $\begin{array}{l}\text { 23. Pogórze Wałbrzysko-Bolkowskie foothills. Zagórze Śląskie, W \& NW exp., } \\
345 \text { m a.s.l., gneiss, Androsacion vandelii [BE84] }\end{array}$ & $+^{*}$ & - & $+^{*}$ \\
\hline $\begin{array}{l}\text { 24. Pogórze Wałbrzysko-Bolkowskie foothills. Bystrzyca Górna, E exp., } \\
340 \text { m a.s.l., gneiss, Androsacion vandelii [BE85] }\end{array}$ & + & - & - \\
\hline
\end{tabular}

\section{Sudetes Mountains}

25. Góry Kaczawskie Mts. Pilchowice, near dam, $\mathrm{N}$ exp., $310 \mathrm{~m}$ a.s.1., basalt, Androsacion vandelii [AE59]

26. Karkonosze Mts. Jagniątków, E exp., $655 \mathrm{~m}$ a.s.l., old stony wall of stream bank, anthropogenic spruce forest

27. Karkonosze Mts. Borowice, E exp., $650 \mathrm{~m}$ a.s.1., old stony wall [AE79]

28. Karkonosze Mts. Chojnik, W exp., $420 \mathrm{~m}$ a.s.1., soil scarp, degraded GalioCarpinetum [AE79]

29. Karkonosze Mts. Chojnik - castle, W exp., $625 \mathrm{~m}$ a.s.1., granite, Androsa cion vandelii [AE79]

30. Góry Kamienne Mts. Krucza Skała, W exp., 670 m a.s.1., trachybasalt, Androsacion vandelii [BE91]

31. Góry Wałbrzyskie Mts. Grzmiąca, E exp., $460 \mathrm{~m}$ a.s.1., greystone, Androsacion vandelii [BE94]

32. Góry Sowie Mts. Kamionki Górne, E exp., 560 m a.s.l., serpentine rock, Androsacion vandelii [BE95]

33. Góry Sowie Mts. Nowa Bielawa, NW exp., $520 \mathrm{~m}$ a.s.1., gneiss, degraded beech forest [BE95]

34. Góry Bardzkie Mts. Bardo, Nysa river valley, SW exp., 230 m a.s.l., mudstone and slate, Androsacion vandelii [BF16]

35. Śnieżnik Massif. Międzygórze, Góra Parkowa Mt., exp. W, 610 m a.s.1., gneiss, Androsacion vandelii [BF47]

indole (DAPI, $2 \mu \mathrm{g} / \mathrm{mL}$ ) for ploidy level, or propidium iodide (PI, $50 \mu \mathrm{g} / \mathrm{mL})$ and ribonuclease A $(50 \mu \mathrm{g} / \mathrm{mL})$ for genome size estimation. Additionally, the buffer was modified by adding $1 \%(\mathrm{w} / \mathrm{v})$ polyvinylpyrrolidone (PVP-10) to neutralize fluorochrome-staining inhibitors present in the cytosol of $P$. vulgare, $P$. interjectum, and $P . \times$ mantoniae and to improve histogram quality. After chopping, the suspension of nuclei was passed through a nylon filter ( $50 \mu \mathrm{m}$ mesh). For ploidy level analysis, 5000-7000 nuclei were measured using a Partec CCA flow cytometer (Münster, Germany), equipped with a mercury UV lamp. For nuclear DNA content, 700010,000 nuclei were measured using a Partec CyFlow SL Green flow cytometer (Münster, Germany) equipped with a laser with green light emission at $532 \mathrm{~nm}$; these analyses were done in five replicates. Histograms were analyzed using FloMax software (Münster, Germany). Nuclear genome size was calculated for $P$. vulgare, $P$. interjectum, and $P$. $\times$ mantoniae using the linear relationship of the ratios between the $2 \mathrm{C}$ peak positions of the target species and P. sativum on the fluorescence intensity histogram. Mean coefficients of variation of the $2 \mathrm{C}$ nuclei were estimated for all samples of the analyzed Polypodium species.

A distribution map was generated on $10 \times 10 \mathrm{~km}$ squares of the ATPOL grid (Zając 1978) using ArcGIS software. Plant community nomenclature follows Matuszkiewicz (2008). 


\section{RESULTS}

Polypodium vulgare was present at all sites examined (164 specimens). At 12 of them we also noted specimens that could not be classified as $P$. vulgare. Eight of those specimens occurred at sites selected as probable habitats based on substrate type, and only 4 of those specimens at randomly chosen sites. We confirmed the presence of $P$. interjectum (16 specimens) and $P . \times$ mantoniae (67 specimens). The results of taxon validation are presented in Table 1.

\section{DNA CONTENT, MICRO- AND \\ MACROMORPHOLOGICAL ANALYSES}

Mean nuclear DNA content determined in our study was $30.63 \pm 0.45 \mathrm{pg} / 2 \mathrm{C}$ for tetraploid $P$. vulgare $(2 \mathrm{n}=4 \mathrm{x}=148), 46.95 \pm 0.47 \mathrm{pg} / 2 \mathrm{C}$ for hexaploid $P$. interjectum $(2 \mathrm{n}=6 \mathrm{x}=222)$, and $38.66 \pm 0.43 \mathrm{pg} / 2 \mathrm{C}$ for pentaploid $P$. $\times$ mantoniae $(2 \mathrm{n}=5 \mathrm{x}=185)$ (Table 2$)$. All samples of a given taxon had the same DNA ploidy level as calculated versus the tetraploid standard, $P$. vulgare.

The ranges of values for all the analyzed traits overlapped across the studied taxa, with the hybrid $P . \times$ mantoniae showing distinctly transitional features (Table 2). Micromorphological features of the annulus were the most diagnostic: $P$. vulgare usually had a single basal cell and numerous annulus cells (12-13), while $2-3$ basal cells and a relatively short annulus with 7-9 indurated cells pointed to $P$. interjectum. Polypodium $\times$ mantoniae showed intermediate values, with 1-2 basal cells and 10-11 indurated cells. The other analyzed micromorphological characters were spore and stomata size. The spores were elliptical or slightly bean-shaped in outline, and reached approximately $60 \mu \mathrm{m}$ along the long axis in P. vulgare, 73-74 $\mu \mathrm{m}$ in $P$. interjectum, and ca $66 \mu \mathrm{m}$ in $P . \times$ mantoniae. On average, stomata cells were $c a 49 \mu \mathrm{m}$ long in $P$. vulgare, ca $58 \mu \mathrm{m}$ long in $P$. interjectum, and ca $54 \mu \mathrm{m}$ long $P$. $\times$ mantoniae, again an intermediate value.

The fronds varied considerably in size, outline and leaf blade/stalk length ratio (Table 3), and varied similarly among all taxa analyzed. There were some differences in venation pattern. More than half of the leaves of $P$. interjectum had trifurcated veins $(57 \%)$, while in $P$. vulgare they were usually bifurcated (64\%). Leaf shape differed slightly between $P$. interjectum and $P$. vulgare: in $P$. interjectum they were mostly oval or lanceolate in outline, and linear leaves were not observed, whereas in $P$. vulgare the leaves were more lanceolate and linear (Fig. 1). The tips of pinnae were acute in $P$. interjectum $(43 \%)$ and rounded in $P$. vulgare (34\%), but the most common forms in both species were leaves with slightly acute tips ( $50 \%$ and $42 \%$ respectively). Fronds of $P$. $\times$ mantoniae showed the entire range of morphological variability of the two parental species. At exposed sites the fronds of all taxa became shorter, much more coriaceous, and more yellow-green than those grown in shade.

\section{DisTRIBUTION AND HABITAT OF POLYPODIUM INTERJECTUM AND P. $\times$ MANTONIAE}

The specimens of $P$. interjectum were found in one location at $c a 360 \mathrm{~m}$ a.s.l. in the Wąwóz Lipa Nature Reserve in the Pogórze Kaczawskie foothills, Western Sudetes (Fig. 2, Table 1), where they occurred together with $P$. vulgare and

Table 2. Results of micromorphological observations and nuclear DNA content analyses for Polypodium vulgare L., P. interjectum Shivas and $P . \times$ mantoniae Rothm., from material of ferns of the populations in the Polish Sudetes.

\begin{tabular}{l|c|c|ccc}
\hline \multirow{2}{*}{ Feature } & \multirow{2}{*}{$\begin{array}{c}\text { Number } \\
\text { of annulus cells }\end{array}$} & $\begin{array}{c}\text { Number } \\
\text { of basal cells }\end{array}$ & $\begin{array}{c}\text { Length of stomata } \\
{[\mu \mathrm{m}]}\end{array}$ & $\begin{array}{c}\text { Length of spores } \\
{[\mu \mathrm{m}]}\end{array}$ & $\begin{array}{c}\text { Nuclear DNA content } \\
{[\mathrm{pg}]}\end{array}$ \\
\cline { 3 - 6 } Taxon & & & min-max [mean \pm SD] \\
\hline P. vulgare & $(7) 11-\mathbf{1 2 - 1 3 - 1 4 ( 1 7 )}$ & $(0) \mathbf{1}(2)$ & $40-59[49.1 \pm 4.38]$ & $44-74[60.1 \pm 4.83]$ & $29.81-31.83[30.63 \pm 0.45]$ \\
$P$. interjectum & $(5) \mathbf{7 - 9}(12)$ & $(1) \mathbf{2}-\mathbf{3}(4-5)$ & $45-66[58.7 \pm 3.13]$ & $54-95[73.2 \pm 5.49]$ & $46.41-47.55[46.95 \pm 0.47]$ \\
$P . \times$ mantoniae & $(4) 8-\mathbf{1 0 - 1 1 - 1 2 ( 1 6 )}$ & $\mathbf{1 - 2 - 3 ( 4 - 5 )}$ & $40-69[54.2 \pm 3.83]$ & $44-95[66.7 \pm 6.91]$ & $38.10-39.79[38.66 \pm 0.43]$ \\
\hline
\end{tabular}




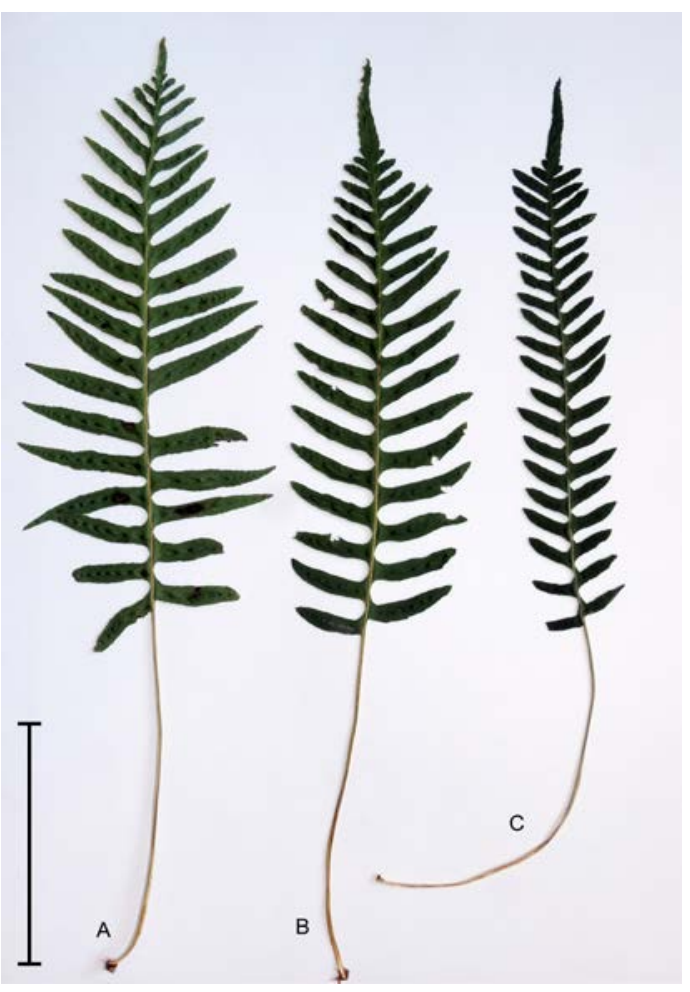

Fig. 1. Leaf outline: A - oval of Polypodium interjectum Shivas (Wąwóz Lipa Nature Reserve), $\mathrm{B}$ - lanceolate of $P$. $\times$ mantoniae Rothm. (Swarna Góra), C - linear of P. vulgare L. (Bogdaszowice). Photo E. Szczęśniak.

$P . \times$ mantoniae, growing in the deep narrow gorge of a small stream. The gorge is carved in greenstone open to the south and protected from cold northwest and north winds. The population colonizes natural rock outcrops shaded by the maple-linden slope forest association Aceri-Tilietum Faber 1936.

Polypodium $\times$ mantoniae was present at 4 randomly selected sites and at 8 of 10 sites chosen for their non-acid substrate. The hybrid was noted in the Sudetes foreland, foothills and mountains (Fig. 2, Table 1) at 270-655 m a.s.1., mainly in the premontane vegetation zone. It was observed to prefer shaded or semi-shaded habitats, mostly on outcrops in forests of the Aceri-Tilietum association. At two localities it was recorded only in pioneer communities of the Androsacion vandellii Br.-Bl. in Br.-Bl. et Jenny 1926 alliance, developed on exposed rock. At one location, $P . \times$ mantoniae was observed in crevices of an old wall.

\section{Discussion}

Delimitation of taxa within the $P$. vulgare complex is difficult and often impossible due to high phenotypic variability, partly resulting from ancient events of polyploidization and interspecific hybridization. To deal with the difficulty we correlated different macro- and micromorphological features with data obtained by the most reliable method for identifying Polypodium cytotypes, flow cytometry, to verify the presence of the three taxa of the $P$. vulgare complex in the Polish Sudetes. To the best of our knowledge these are the first reliable data on P. interjectum in the Polish flora, and the second on $P$. $\times$ mantoniae (Zenkteler \& Jędrzejczyk 2012) but the first for the region.

Table 3. Size and macromorphological characters of leaves of Polypodium vulgare L., P. interjectum Shivas and $P$. $\times$ mantoniae Rothm. from the analyzed populations.

\begin{tabular}{|c|c|c|c|c|c|c|c|}
\hline \multirow[b]{2}{*}{ Taxon } & \multicolumn{3}{|c|}{$\begin{array}{l}\text { Length of leaf }(\mathrm{cm}) \\
\text { min-max [mean] }\end{array}$} & \multirow{2}{*}{$\begin{array}{l}\text { Blade to } \\
\text { stalk ratio }\end{array}$} & \multicolumn{3}{|c|}{ Leaf characteristics } \\
\hline & $\begin{array}{l}\text { whole } \\
\text { frond }\end{array}$ & stalk & blade & & $\begin{array}{c}\text { shape } \\
\text { of leaf blade }\end{array}$ & tip of pinnae & $\begin{array}{l}\text { venation (number } \\
\text { of forks) }\end{array}$ \\
\hline P. vulgare & $\begin{array}{l}16-47 \\
{[30.1]}\end{array}$ & $\begin{array}{c}5.5-18 \\
{[11.2]}\end{array}$ & $\begin{array}{c}9.5-31 \\
{[19.8]}\end{array}$ & $\begin{array}{c}1.0-2.6 \\
{[1.7]}\end{array}$ & $\begin{array}{l}\text { linear }-38 \% \\
\text { lanceolate }-42 \% \\
\text { oval }-20 \%\end{array}$ & $\begin{array}{l}\text { rounded }-34 \% \\
\text { slightly acute }-42 \% \\
\text { acute }-24 \%\end{array}$ & $\begin{array}{l}(1) 2-64 \% \\
3(4)-36 \%\end{array}$ \\
\hline P. interjectum & $\begin{array}{l}24-41 \\
{[32.1]}\end{array}$ & $\begin{array}{c}6-18.5 \\
{[11]}\end{array}$ & $\begin{array}{l}15-30 \\
{[21.4]}\end{array}$ & $\begin{array}{c}1.0-3.8 \\
{[2.0]}\end{array}$ & $\begin{array}{l}\text { linear }-0 \% \\
\text { lanceolate }-43 \% \\
\text { oval }-57 \%\end{array}$ & $\begin{array}{l}\text { rounded }-7 \% \\
\text { slightly acute }-50 \% \\
\text { acute }-43 \%\end{array}$ & $\begin{array}{l}2-43 \% \\
3-57 \%\end{array}$ \\
\hline $\begin{array}{l}P . \quad \times \operatorname{man}- \\
\text { toniae }\end{array}$ & $\begin{array}{c}15,5-58 \\
{[31.7]}\end{array}$ & $\begin{array}{c}6-18 \\
{[11.1]}\end{array}$ & $\begin{array}{l}10-30 \\
{[19.3]}\end{array}$ & $\begin{array}{c}1.1-2.9 \\
{[1.9]}\end{array}$ & $\begin{array}{l}\text { linear }-10 \% \\
\text { lanceolate }-62 \% \\
\text { oval }-28 \%\end{array}$ & $\begin{array}{l}\text { rounded }-36 \% \\
\text { slightly acute }-33 \% \\
\text { acute }-31 \%\end{array}$ & $\begin{array}{c}(1) 2-53 \% \\
3-47 \%\end{array}$ \\
\hline
\end{tabular}




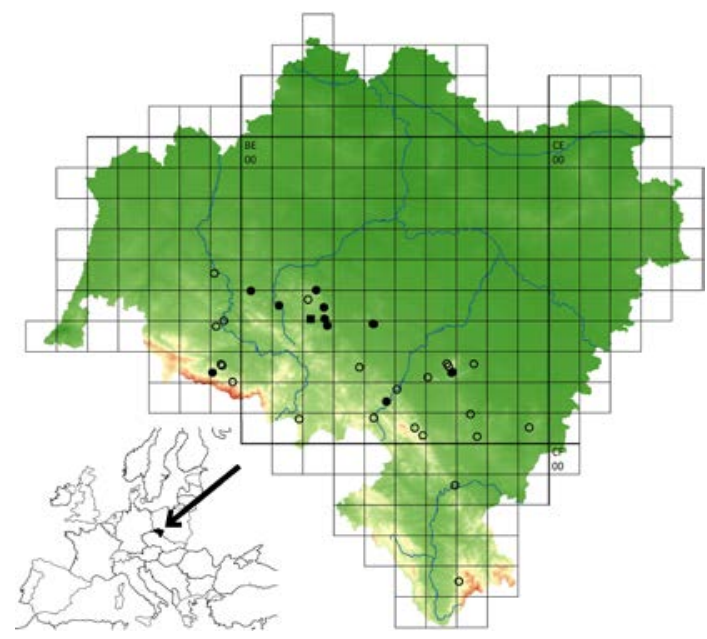

Fig. 2. Distribution of research locations and taxa in $10 \times 10 \mathrm{~km}$ squares of the ATPOL grid: $\bigcirc-$ only Polypodium vulgare L., - - P. vulgare and P. × mantoniae Rothm., - - P. vulgare, P. $\times$ mantoniae and $P$. interjectum Shivas.

Polypodium interjectum was earlier reported from the Eastern Sudetes (Niski Jesionik range) and the foothills of the Western Sudetes (Pogórze Łużyckie foreland) in the Czech Republic (Čvančara 1987; Bureš et al. 2003) and Germany (Hardtke \& Ihl 2000). The new Polish locality supplements the range of the species, which reaches the regional northeastern border of its continental range in western and southwestern Poland. New localities of this fern are quite likely to be found, in view of its distribution in German and Czech parts of the Sudetes and in the vicinity of the Moravian Gate (Čvančara 1987; Benkert et al. 1998; Hardtke \& Ihl 2000; Bureš et al. 2003), as well as the presence of its hybrid and of favorable habitats in the Polish Sudetes.

The hybrid $P . \times$ mantoniae was earlier reported and confirmed by flow cytometry on Wolin Island (Zenkteler \& Jędrzejczyk 2012). The present research indicated that it often co-occurs in dense mats together with the parental species $P$. vulgare, from which it is difficult to distinguish. Our preliminary survey suggests that $P . \times$ mantoniae is rather common in western Poland, especially at lower locations in the Sudetes, but the overall distribution of this hybrid in Poland needs to be determined through detailed studies and revision.
It is often a problem to determine $P$. interjectum and $P$. $\times$ mantoniae based only on macromorphological characters, since the size and shape of fronds as well as the venation pattern strongly depend on habitat conditions (Shivas 1961b). Polypodium interjectum is usually a larger plant than $P$. vulgare (which occurs in the same habitats in the Polish Sudetes), and its fronds are more oval in shape and have more acute pinnae. Its sori are pale yellow to brown (not orange as in $P$. vulgare) and oval in shape; the annulus is often bicolor or pale brown. According to the literature (Shivas 1961b; Hršak 2000; Bureš et al. 2003), however, these characters are variable and thus not diagnostic for $P$. interjectum. Moreover, all of these characteristics are observed in some specimens of $P . \times$ mantoniae, as the hybrid presents a wide range of morphological variability between the parental species. More reliable are micromorphological features such as annulus structure, which can be useful in delimiting particular taxa of the P. vulgare complex (Szczęśniak et al. 2012). The numerical values obtained in our work are similar to those given in the species diagnosis (Shivas 1961b) and literature (e.g., Hršak 2000; Bureš et al. 2003; Helánová et al. 2004). An exception was the number of indurated annulus cells which Ivanova (2006) found in P. interjectum in Bulgaria, reaching the relatively high value of $9-14(-20)$ cells, overlapping with the 11-13 indurated cells of $P$. vulgare; the overlap prompted her to question the diagnostic value of this character in the Bulgarian specimens.

Useful features for species identification are traits known to be related to the ploidy level of a taxon: spore and stomata size (e.g., Stebbins 1971; Kott \& Britton 1982; Przywara et al. 1988; Joachimiak \& Grabowska-Joachimiak 2000; Aryavand et al. 2003; Beck et al. 2003, 2010; Gabriel y Galán et al. 2011). Recently they were used for re-identification of Polypodium vouchers from the Botanical Museum of the Finnish Museum of Natural History (Harmaja 2012). However, the measured sizes of spores and stomata given in the literature for the $P$. vulgare complex are quite variable (Benoit 1966; Bureš et al. 2003; Helánová et al. 2004; Ivanova 2006). All published sources 
generally bear out the same tendency: the stomata size values for $P$. vulgare (tetraploid) are lower than those for P. interjectum (hexaploid), with size ranges overlapping only slightly. The natural hybrid between those two taxa (pentaploid $P$. $\times$ mantoniae) shows intermediate size values. Spore size presents a similar tendency (Bureš et al. 2003; Helánová et al. 2004; Ivanova 2006). Our results are in accord with the general tendency, although particular values are closer to the lower extreme.

Discrepancies between specific values can be due to the method of measurement (the use of a microscope ocular or software can introduce different degrees of accuracy), differences in stomata size depending on the degree of pore opening, and/or phenotypic variability of a species due to environmental factors.

Interestingly, the material we examined contained many abortive spores and sporangia. Such a phenomenon is well known for triploid or pentaploid taxa, which due to difficulties with meiotic division frequently produce distorted indehiscent sporangia and only a few, often abnormal spores (Kott \& Britton 1982; Ivanova 2006). Thus the high number of abortive spores we noted in pentaploid $P$. $\times$ mantoniae is not surprising; the hybrid also often produced sterile leaves or leaves with only small marks at sites of potential sporangia. Polypodium interjectum is a stable hexaploid which usually forms normal sporangia and spores.

In many cases the only reliable ways to identify a taxon are to count the number of chromosomes or to estimate nuclear DNA content and calculate the ratio of a particular taxon's DNA. The average 2C DNA content of tetraploid $P$. vulgare determined in our study was $30.63 \mathrm{pg}$, very similar to the value reported by Zenkteler and Jędrzejczyk (2012) and close to the genome size published by Murray (1985) and Bureš et al. (2003). For hexaploid $P$. interjectum we found DNA content to be $46.95 \mathrm{pg} / 2 \mathrm{C}$, similar to the value published by Bureš et al. (2003) but differing from the 39.32 pg reported by Murray (1985) and the $37.50 \mathrm{pg}$ given by Redondo et al. (1999). For the pentaploid hybrid $P . \times$ mantoniae, genome size was $38.66 \mathrm{pg} / 2 \mathrm{C}$, similar to that determined by Zenkteler and Jędrzejczyk (2012) and Bureš et al.
(2003) but differing from the $35.66 \mathrm{pg}$ reported by Murray (1985) and the 31.5 pg found by Redondo et al. (1999). Loureiro et al. (2005) stated that such differences between laboratories are common and can result from, for example, the use of different estimation methods, nuclei isolation buffers, DNA staining fluorochromes or internal standards. The coefficients of variation obtained for $P$. vulgare (mean 4.81\%), P. interjectum (mean $4.55 \%$ ) and $P$. $\times$ mantoniae (mean $4.30 \%$ ) were very close to the acceptance value of $5 \%$ (Doležel \& Bartoš 2005).

ACKNOWLEDGEMENTS. We are grateful to the Regional Directorate of Environmental Protection in Wrocław for granting permission to conduct research and collect samples in the following nature reserves: Nad Groblą, Wąwóz Myśliborski, Wąwóz Siedmicki, Wąwóz Lipa, Ostrzyca Proboszczowicka, Góra Radunia, Góra Ślęża, and Przełomy pod Książem koło Wałbrzycha (permit no. WPN.6205.73.2012.MR.1, 06.06.2012); and to the anonymous reviewers for valuable comments and suggestions on the manuscript. This research was funded in part by the University of Wrocław (grant no. 1070/S/KNOSR/2013).

\section{REFERENCES}

Aryavand A., Ehdaie B., Tran B. \& Waines J. G. 2003. Stomatal frequency and size differentiate ploidy level in Aegilops neglecta. Genet. Resour. Crop Evol. 50: 175-182.

Beck S. L., Dunlop R. W. \& Fossey A. 2003. Stomatal length and frequency as a measure of ploidy level in black wattle, Acacia mearnsii (de Wild). Bot. J. Linn. Soc. 141: 177-181.

Beck J. B., Windham M. D., Yatskievych G. \& Pryer K. M. 2010. A diploid-first approach to species delimitation and interpreting polyploid evolution in the fern genus Astrolepis (Pteridaceae). Syst. Bot. 35(2): 223-234.

Benkert D., FukareK F. \& Korsch H. 1998. Verberitungatlas der Farn- und Blütenpflanzen Ostdeutschlands. Gustav Fischer, Jena Stuttgart, Lübeck, Ulm.

Benoit P. M. 1966. Some recent work in Wales on the Polypodium vulgare aggegate. Brit. Fern Gaz. 9: 277-282.

Bureš P., TichÝ L., WANG F. \& Bartoš J. 2003. Occurrence of Polypodium $\times$ mantoniae and new localities for $P$. interjectum in the Czech Republic confirmed using flow cytometry. Preslia 75(4): 293-310.

ČvanČara A. 1987. Polypodium L. - osladič. In: S. HeJnÝ \& B. SLAvíK (eds), Květena ČSR. 1: 280-282, Academia, Praha. 
DoležEl J. \& BARToš J. 2005. Plant DNA flow cytometry and estimation of nuclear genome size. Ann. Bot. 95: 99-110.

Dostál J. \& Reichstein T. 1984. Polypodium L. In: K. U. Kramer (ed.), Gustav Hegi Illustrierte Flora von Mitteleuropa. 1(1): 279-285, Paul Parey, Berlin - Hamburg.

Fedorov A. A. (ed.) 1974. Flora partis europaeae URSS. 1. Nauka, Leningrad (in Russian).

Gabriel y Galán J. M., Prada C., Rolleri C. H., Lahoz-BelTRÁ R. \& MARTínez-CALVO C. 2011. Biometry of stomata in Blechnum species (Blechnaceae) with some taxonomic and ecological implications for the ferns. Rev. Biol. Trop. 59(1): 403-415.

Galbraith D. W., Harkins K. R., Maddox J. M., Ayres N. M., Sharma D. P. \& Firoozabady E. 1983. Rapid flow cytometric analysis of the cell cycle in intact plant tissues. Science 220: 1049-1051.

Hardtke H.-J. \& Ihl A. 2000. Atlas der Farn- und Samenpflanzen Sachsens. Sächsisches Landesamt für Umwelt und Geologie, Dresden.

Harmaja H. 2012. The oldest record of Polypodium interjectum in Sweden, with notes on the variability of $P$. vulgare. Ann. Bot. Fenn. 49: 13-20.

Hassler M. \& Swale B. 2001. Checklist of world ferns. [May 2015]. http://homepages.caverock.net.nz/ bj/fern.

Haufler C. H., Windham M. D., Lang F. A. \& Whitmore S. A. 1993. Polypodium Linneus. In: Flora of NORTH America Editorial Committee (ed.), Flora of North America north of Mexico. 2: 315-323. Oxford University Press, New York \& Oxford.

Helánová K., Bureš P., Šmarda P. \& Horová L. 2004. Polypodium $\times$ mantoniae $(P$. interjectum $\times P$. vulgare $)$ new hybrid in Romania, confirmed using flow cytometry. Contribuţii Botanice 39: 7-11.

Hennipman E., Veldhoen P. \& Kramer K. U. 1990. Polypodiaceae. In: K. U. Kramer \& P. S. Green (eds), The Families and Genera of Vascular Plants. 1: 203-230. Springer-Verlag, Berlin-Heidelberg.

Holub J. \& Kubát K. 1999. Polypodium interjectum Shivas. In: J. Čerowský, V. Feráková, J. Holub, S. MaglockÝ \& F. ProcházKa (eds), Červená kniha ohrožených a vzácných druhů rostlin a živočichů $\check{C} R$ a SR. 5: 290. Príroda, Bratislava.

HrŠAK V. 2000. Two fern taxa from the Polypodium vulgare L. complex - new for Croatia. Acta Bot. Croat. 59(2): 375-381.

Ivanova D. 2006. Polypodium interjectum and $P . \times$ mantoniae (Polypodiaceae: Pteridophyta), new to the Bulgarian flora. Phytologia Balcan. 12: 191-202.

JoAChimiak A. \& GrabowSKa-JoAChimiak A. 2000. Stomatal cell length and ploidy level in four taxa belonging to the Phleum sect. Phleum. Acta Biol. Cracov. Ser. Bot. 42: 103-107.
KotT L. S. \& BRitTon D. M. 1982. A comparative study of sporophyte morphology of the three cytotypes of Polypodium virginianum in Ontario. Canad. J. Bot. 60: 1360-1370.

KubÁT K. 2002. Klíč ke květeně České Republiky. Academia, Praha.

Loureiro J., Pinto G., Lopes T., Doležel J. \& Santos C. 2005. Assessment of ploidy stability of the somatic embryogenesis process in Quercus suber L. using flow cytometry. Planta 221: 815-822.

Lu S. \& Haufler C. 2013. Polypodium Linnaeus, Sp. Pl. 2: 1082.1753. In: Z. Y. Wu, P. H. Raven \& D. Y. Hong (eds.), Flora of China. 2-3: 838-839. Science Press, Beijing \& Missouri Botanical Garden, St. Louis.

Manton I. 1947. Polyploidy in Polypodium vulgare. Nature 159: 136.

Manton I. 1950. Problems of cytology and evolution in the Pteridophyta. Cambridge University Press, Cambridge.

MatuszKiewicz W. 2008. Przewodnik do oznaczania zbiorowisk roślinnych Polski. Wydawnictwo Naukowe PWN, Warszawa.

MiLdE J. 1858. Die Gefäss-Cryptogamen in Schlesien preussischen und österreichischen Antheils. Nova Acta Acad. Caes. Leop.-Carol. German. Nat. Cur. 26(2): 371-753.

Mirek Z., PięKoś-Mirkowa H., ZająC A. \& ZająC M. 1995. Vascular plants of Poland: a checklist. W. Szafer Institute of Botany, Polish Academy of Sciences, Kraków.

Mirek Z., Piękoś-Mirkowa H., ZająC A. \& ZająC M. 2002. Flowering plants and pteridophytes of Poland: a checklist. W. Szafer Institute of Botany, Polish Academy of Sciences, Kraków.

MurRay B. G. 1985. Karyotypes and nuclear DNA amounts in Polypodium L. (Polypodiaceae). Bot. J. Linn. Soc. 90(3): 209-216.

Nielsen H. \& Johnsen J. I. 2000. Polypodium. In: B. Jonsell (ed.), Flora Nordica. 1: 41-42. Royal Swedish Acad. Sci., Stockholm.

PAGe C. N. 2004. The ferns of Britain and Ireland. Second edition. Cambridge University Press, Cambridge.

Przywara L., Pandey K. K. \& Sanders P. S. 1988. Length of stomata as an indicator of ploidy level in Actinidia deliciosa. New Zealand J. Bot. 26: 179-182.

Redondo N., Blanco A. \& Horjales M. 1999. Estudio del género Polypodium L. del noroeste Ibérico: Cantidades de DNA nuclear. Nova Acta Cientifica Compostelana (Bioloxía) 9: 109-116.

Rothmaler W. 1929. Die Pteridophyten Thüringens. Mitt. Thüring. Bot. Ver, N.F. 38: 92-248.

Rothmaler W. 1994. Excursionflora von Deutschland. 4. Spectrum Academischer Verlag, Berlin.

RUTKOWSKi L. 2006. Klucz do oznaczania roślin naczyniowych Polski niżowej. Wydawnictwo Naukowe PWN, Warszawa. 
Seregin A. 2008. Contribution to the vascular flora of the Sevastopol area (the Crimea): a checklist and new records. Fl. Medit. 18: 171-246.

Shivas M. G. 1961a. Contributions to the cytology and taxonomy of species of Polypodium in Europe and America. I. Cytology. Bot. J. Linn. Soc. 58: 13-25.

Shivas M. G. 1961b. Contributions to the cytology and taxonomy of species of Polypodium in Europe and America. II. Taxonomy. Bot. J. Linn. Soc. 58: 27-38.

Shivas M. G. 1962. The Polypodium vulgare complex. Brit. Fern Gaz. 9: 65-70.

ŚLIWINSKa E., ZiELIŃSKa E. \& JęDRZEJCZYK I. 2005. Are seeds suitable for flow cytometric estimation of plant genome size? Cytometry 64A: 72-79.

Stebins G. L. 1971. Chromosomal evolution in higher plants. Edward Arnold Ltd., London.

SzczęŚniak E., Zenkteler E., Gola E. M. \& JędrZejczyK I. 2012. The genus Polypodium L. in Poland - a key to the species determination. In: E. SzCZĘŚNIAK \& E. Gola (eds),
Genus Polypodium in Poland, pp. 5-25. Polish Botanical Society, Wrocław.

Valentine D. H., Akeroyd J. R. \& Jermy A. C. 1993. Polypodium L. In: T. G. Tutin, N. A. Burges, A. O. Chater, J. R. Edmondson, V. H. Heywood, C. M. Moore, D. H. Valentine, S. M. Walters \& D. A. WebB (eds), Flora Europaea. Second edition. 1: 15-16. Cambridge University Press, Cambridge.

Vaszeka O. V. \& Bezsmertna O. O. 2012. Atlas paprotiej flory Ukrainy. Taras Szewczenko Kijewskij Naszonalnij Universitet, Kijev.

ZAJĄC A. 1978. Atlas of distribution of vascular plants in Poland (ATPOL). Taxon 27(5/6): 481-484.

ZAJĄC A. \& ZAJĄC M. (eds) 2001. Distribution Atlas of Vascular Plants in Poland. Laboratory of Computer Chorology, Institute of Botany, Jagiellonian University, Cracow.

ZENKTEler E. \& JęDrZEJCZYK I. 2012. Morphology and anatomy of the rhizome of Polypodium $\times$ mantoniae Shivas. In: E. SzCZĘŚNiaK \& E. Gola (eds), Genus Polypodium L. in Poland, pp. 27-38. Polish Botanical Society, Wrocław. 